Journal of Energy and
Environmental Sustainability
Journal homepage : www.jees.in

\title{
Biological nitrogen removal from wastewater by Paracoccus denitrificans ISTOD1: optimization of process parameters using response surface methodology
}

\author{
Kristina Medhi, Asmita Gupta and Indu Shekhar Thakur* \\ School of Environmental Sciences, Jawaharlal Nehru University, New Delhi, India
}

\section{A R T I C L E I N F O}

Received : 12 February 2018

Accepted : 12 March 2018

Keywords:

P.denitrificans, Response Surface Methodology, Ammonia removal, Nitrogen balance analysis, Preoptimization

\begin{abstract}
A B S T R A C T
In freshwater ecosystems, the vital biogenic constituent is nitrogen and the increasing nutrient load discharge from wastewaters has turned into a more grievous issue. A previously demonstrated bacterial strain Paracoccus denitrificans ISTOD1 was studied for the bioremoval of nitrogen in the form ammonia$\mathrm{N}$ from synthetic wastewater media. A high concentration of $\mathrm{NH}_{4}^{+}-\mathrm{N}$ of $100 \mathrm{mg} / \mathrm{L}$ was used to study the behavioral pattern of the bacterial strain during the utilization process. Pre-optimization experiments with different culture conditions for the strain ISTOD1 exhibited high ammonia removal efficiency of $83.9 \%, 75.7 \%$ and $76.23 \%$ in presence of glucose as C-source, $\mathrm{pH} 7$ and temperature of $30^{\circ} \mathrm{C}$ respectively. Optimization of process parameters for enhancing the heterotrophic nitrification and denitrification process in synthetic wastewater done using the Response Surface Methodology (RSM) showed 98.2\% and $91.8 \%$ reduction in the concentration of ammonia and nitrate, respectively as compared to the preoptimized conditions. Nitrogen balance analysis revealed that approximately $67 \%$ of $\mathrm{NH}_{4}^{+}-\mathrm{N}^{+}$as removed as gas products and $32.4 \%$ was transformed into biomass. This study helps in developing a biodegradation treatment method under aerobic conditions suitable for purification of ammonia-rich wastewater and eliminating the by-product such as $\mathrm{NO}_{3}^{-} \mathrm{N}$ involved in polluting the receiving waters.
\end{abstract}

(C) 2018 ISEES, All rights reserved

\section{Introduction}

One of the major environmental problems presently is the emerging nitrogen pollution caused by the continuous accumulation of nitrogenous compounds in the form of ammonia, nitrite and nitrate nitrogen in the surrounding environment. The increasing civilization and human activities has led to negative consequences leading to excessive amount of organic contaminants and nitrogenous wastewater which includes industrial, domestic, agricultural wastewater etc. being discharged into the surrounding fresh water bodies [Gao at al., 2014; Wang et al., 2016; Gupta and Thakur, 2015]. The presence of uncontrolled discharges of wastewater containing high concentration of aqueous ammonia leads oxygen depletion, increase occurrence of pathogenic microorganisms, is toxic to the fish and nitrate damages their immune system as a result it ultimately affects the human health through bioaccumulation [Huang et al., 2017; Grguric et al., 2000]. Therefore, there is an urgent need for a stringent research so that the nitrogen-containing wastewater could be effectively purified before discharging.

Physical, chemical and biological approaches help in the conventional removal of nitrogen from both wastewater and natural water. However, biological treatment approach has proved to be more advantageous compared to others due to its ease of implementation, being eco as well as pocket friendly. Biological nitrogen removal in wastewater is usually carried out by the nitrification-denitrification processes in a two-stage treatment process. Recently, researchers are focusing on the applicability of a single-stage treatment approach though simultaneous nitrification and denitrification (SND). Microbes that are capable of conducting heterotrophic oxidation of $\mathrm{NH}_{4}^{+}-\mathrm{N}$ and reducing the nitrification products, $\mathrm{NO}_{2}^{-}$and $\mathrm{NO}_{3}{ }^{-}$completely under aerobic conditions are gaining attention and have been reported for high ammonia removal efficiency such as Paracoccus denitrificans ISTOD1 [Medhi et al., 2017], Diaphorobacter sp. [Ge et al., 2015], Agrobacterium sp. LAD9 [Chen and Ni, 2012], Acinetobacter sp. HA2 [Yao et al. 2013], Vibrio diabolicus SF16 [Duan et al., 2015], Bacillus sp. YX-6 [Song et al., 2011].

The major factors affecting the heterotrophic nitrification-aerobic denitrification process are carbon source, $\mathrm{C}: \mathrm{N}$ ratio, temperature, initial $\mathrm{pH}$, shaking speed and dissolved oxygen (DO) concentration. Previous studies have shown that different species of bacteria have their own distinct response to these parameters [Chen and $\mathrm{Ni}, 2012$; Niel et al., 1992]. However, if the influence strength of these factors and their interactions on the heterotrophic nitrification-aerobic denitrification process are systematically evaluated, it will help in better understanding of the mechanism. Therefore, to evaluate valuable parameters which affect a process, Response surface methodology (RSM), a combination of mathematical and statistical methods for the design of experiments assists with the main objective of optimizing the process. It is widely used as an effective statistical method in various fields [Asadi and Zilouei, 2017].

This present study investigates a novel bacterium Paracoccus denitrificans ISTOD1 isolated from the wastewater samples of a municipal sewage treatment plant showing characteristic nitrogen removal pathway. The objective of the study was to optimize the physico-chemical conditions required to remove ammonia and nitrate nitrogen from synthetic 
wastewater. In previous studies, people have paid more attention to the conditions, like temperature, $\mathrm{pH}, \mathrm{C}: \mathrm{N}$ ratio but reports on duration are limited. Herein, the factors affecting the performance of strain ISTOD1 in estimating the maximum nutrient degradation were comprehensively evaluated based on the RSM analysis, and the possible nitrogen removal pathway was explored through the nitrogen mass balance analysis.

\section{Material and methods}

\subsection{Microorganism and culture condition}

A previously reported potent bacterial strain Paracoccus denitrificans ISTOD1 (gene bank accession number - KX417305) isolated from influent waste water samples collected from Okhla Sewage Treatment Plant (OK STP) located at JasolaVihar, New Delhi, India $\left(28^{\circ}\right.$ $32^{1} 52.9069^{\circ} \mathrm{N}$ and $77^{\circ} 16^{1} 36.7867^{\circ} \mathrm{E}$ ) was used for the study of heterotrophic nitrification and aerobic denitrification [Medhi et al., 2017]. The bacterial strain was grown in Luria Bertani (LB) medium composed of (g/L): tryptone, 10; yeast extract, $5 ; \mathrm{NaCl}, 10$ for $24 \mathrm{~h}$, was harvested by centrifugation at $8000 \mathrm{rpm}$ for $10 \mathrm{~min}$ and washed twice with sterile distilled water. $2 \%$ of the cultured pellet was resuspended in $50 \mathrm{ml}$ of synthetic basal medium (SBM) for inoculation. The composition of $\mathrm{SBM}(\mathrm{g} / \mathrm{L})$ was as follows: $\left(\mathrm{NH}_{4}\right)_{2} \mathrm{SO}_{4}$; glucose; $\mathrm{NaCl}, 4$; $\mathrm{Na} 2 \mathrm{HPO} 4.12 \mathrm{H} 2 \mathrm{O} ; 21.5$, of $\mathrm{KH} 2 \mathrm{PO} 4,0.9$ and $3 \% \mathrm{v} / \mathrm{v}$ trace elements solution. The trace elements solution was prepared as accordingly described in Medhi et al., [2017]. The prepared media had a $\mathrm{pH}$ of 7.3. The concentrations of $\left(\mathrm{NH}_{4}\right)_{2} \mathrm{SO}_{4}$ as the sole nitrogen source and glucose as carbon source were adjusted maintaining at a $\mathrm{C}: \mathrm{N}$ ratio $(\mathrm{w} / \mathrm{w})$ of 10 , incubated under aerobic conditions at $30^{\circ} \mathrm{C}$ and $150 \mathrm{rpm}$.

\subsection{Selection of conditions for pre-optimization}

\subsubsection{Selection of ammonium concentration}

The influence of the ammonium concentration on the nitrification and denitrification capacity of $P$. denitrificans ISTOD1 was assessed in SBM. Initial $\mathrm{NH}_{4}{ }^{+}-\mathrm{N}$ concentrations were adjusted to 50,100 and $350 \mathrm{mg} / \mathrm{L}$ $\mathrm{NH}_{4}^{+}-\mathrm{N}$ using $\left(\mathrm{NH}_{4}\right)_{2} \mathrm{SO}_{4}$. During incubation, the cultures were sampled periodically to determine optical density $\left(\mathrm{OD}_{600}\right)$ and the levels of $\mathrm{NH}_{4}^{+}$$\mathrm{N}$ at regular intervals for $48 \mathrm{~h}$. The percent removal of ammonium determined the best concentration to be taken for further analyses. The culture conditions were as described above. All the tests were conducted in triplicates.

\subsubsection{Selection of carbon source}

Strain ISTOD1 was cultured in SBM described above with the addition of the following carbon compounds: glucose $(2 \% \mathrm{w} / \mathrm{v})$, sucrose $(2 \% \mathrm{w} /$ v) and molasses ( $2 \% \mathrm{v} / \mathrm{v})$ as carbon sources. Medium was supplemented with filter sterilized glucose and sucrose. $10 \%$ molasses as a final concentration from $5 \%$ liquor (stock) was prepared by diluting with distilled water and autoclaved. The solution was then left overnight for settling and $2 \%$ clarified molasses was used. The amount of each carbon source was adjusted to give a $\mathrm{C}: \mathrm{N}$ ratio of 10 with a constant concentration of $\mathrm{NH}_{4}^{+}-\mathrm{N}$. $2 \%$ of the bacterial culture from LB medium was inoculated in $\mathrm{SBM}$ and cultured at $30^{\circ} \mathrm{C}, 150 \mathrm{rpm}$. Aliquots were collected periodically for chemical analysis and cell growth. All the tests were performed in triplicates.

\subsubsection{Estimation of $p H$ and temperature range}

The strain ISTOD1 was inoculated into the LB medium and cultured at $30^{\circ} \mathrm{C}$ for $16-18 \mathrm{~h}$ until the value of $\mathrm{OD}_{600}$ reached 1.0 . The culture was centrifuged at $8000 \mathrm{rpm}$ at $10 \mathrm{~min}$ and the washed pellet $(1 \% \mathrm{w} / \mathrm{v})$ was then resuspended in $50 \mathrm{~mL}$ of SBM as inoculum containing $100 \mathrm{mg} / \mathrm{L}$ of $\mathrm{NH}_{4}{ }^{+}-\mathrm{N}$. The cultures were incubated at $\mathrm{pH}$ of 4,7 and 10 whereas temperature ranges were $15^{\circ} \mathrm{C}, 30^{\circ} \mathrm{C}$ and $40^{\circ} \mathrm{C}$ for $48 \mathrm{~h}$. The samples were collected at a $4 \mathrm{~h}$ interval to detect the cell growth and the remaining ammonium concentration for evaluating the ammonium removal efficiency at both the parameters. All the tests were conducted in triplicates.

\subsection{Analytical methods}

The growth of the isolate was measured by Varian Carry 100 Bio spectrophotometer at a wavelength of $600 \mathrm{~nm}$. Ammonia was determined by the Phenate method at a wavelength of $640 \mathrm{~nm}$ and nitrite was determined by N-(1-naphthyl)-ethylene diamine photometry method at a wavelength of $543 \mathrm{~nm}$, as per standard methods given in APHA [2012]. Nitrate was measured by Phenol Disulphonic Acid (PDA) method at a wavelength of $410 \mathrm{~nm}$ [CPCB, 2010]. TN amount was calculated by adding concentrations of ammonia-N, nitrate- $\mathrm{N}$ and nitrite-N. Intracellular nitrogen content was calculated by subtracting the $\mathrm{TN}$ of inoculated medium following centrifugation $\left(4^{\circ} \mathrm{C}, 15 \mathrm{~min}, 3600 \mathrm{~g}\right)$ from the $\mathrm{TN}$ of non-centrifuged medium [Yang et al., 2011].Percent reduction was calculated by the formula $\left(C_{i}-C_{f}\right) / C_{i} * 100$ where, $C_{i}$ is the initial concentration and $\mathrm{C}_{\mathrm{f}}$ is the final concentration. All the statistical analysis in this work was analyzed by Microsoft excel and Sigma plot SPSS11.0 software.

\subsection{Box-behnken design for optimization of the environmental factors influencing nitrification and denitrification process}

Response Surface Methodology (RSM) was used to investigate the effects of initial $\mathrm{C}: \mathrm{N}$ ratio, $\mathrm{pH}$ and duration on the activity of heterotrophic nitrification-aerobic denitrification by the strain P.denitrificans ISTOD1. $2 \%$ of the bacterial culture from LB medium was inoculated in $100 \mathrm{ml}$ of $\mathrm{SBM}$ in $250 \mathrm{ml}$ flasks and incubated at $30^{\circ} \mathrm{C}, 150 \mathrm{rpm}$. The amount of carbon source was changed to adjust the $\mathrm{C}: \mathrm{N}$ ratios in the SBM by maintaining a constant ammonia nitrogen concentration at $104.34 \mathrm{mg} / \mathrm{L}$.

\subsubsection{Experimental design}

The levels of the three independent variables ( $\mathrm{C}: \mathrm{N}$ ratio, $\mathrm{pH}$, duration) were defined according to Box-Behnken design (BBD). 17 experiments were required to assess the effects of the three independent variables for the procedure (Table 1), each at three different concentration levels of low (-1), medium (0) and high (+1) on two responses, ammonia removal (mg/L) and nitrate removal (mg/L) for simultaneous nitrification and denitrification. The experimental design matrix derived from the BoxBehnken model with the coded levels (minimum, medium and maximum) and actual values of the three variables chosen for these 17 different sets of experiment [Gupta and Thakur, 2016]. A genuine replicate was done to estimate the experimental error. The statistical experimental designs and graphical analysis were performed with the help of Design Expert 11 software (Stat-Ease Inc., Minneapolis, USA).

\subsection{Nitrogen balance analysis}

For Nitrogen testing, the optimized conditions $(\mathrm{pH}, \mathrm{C}: \mathrm{N}$ ratio, duration) obtained in the RSM analysis were used for the experiment The nitrogen balance and removal efficiency for heterotrophic nitrification and aerobic denitrification was observed in $250 \mathrm{ml}$ flasks. Strain ISTOD1 was inoculated in $100 \mathrm{ml}$ of SBM having $100 \mathrm{mg} / \mathrm{L} \mathrm{NH}_{4}^{+}-\mathrm{N}$ as fixed amount of initial nitrogen concentration. The flask was incubated at $30^{\circ} \mathrm{C}$, $150 \mathrm{rpm}$. All tests were carried out in triplicates. Aliquots of $2 \mathrm{ml}$ were collected periodically for the detection of ammonia nitrogen, nitrite, nitrate and intracellular $\mathrm{N}$.

\section{Results and discussion}

\subsection{Strain selection}

P.denitrificans ISTOD1 colony morphology after incubating for $24 \mathrm{~h}$ at $30^{\circ} \mathrm{C}$ on LB plates were small circular shaped, opaque with smooth edges, creamy white color. Gram staining confirmed it as a gram-negative strain. The described potent heterotrophic nitrification- aerobic denitrification strain ISTOD1 was amplified and sequenced using 16S rDNA gene and then was submitted to GenBank database with an accession number - KX417305, an indigenous bacterium isolated from the influent wastewater samples of OK STP, was used for the optimization studies for nitrogen removal. Paracoccus denitrificans has been previously studied as a model organism for the study of denitrification [Baker et al., 1998] after its pioneered discovery of aerobic denitrification ability to perform single stage nitrogen removal process [Robertson and Kuenen, 1984]. This denitrifier strain has been well reported for nitrification-denitrification process aerobically as well as anaerobically [Medhi et al., 2017]. Keeping in view of the above literatures, $P$. denitrificans ISTOD1, being a potent bacterial strain was selected for study of bioremoval of nutrient (nitrogen) present in wastewater.

\subsection{Pre-optimization conditions}

\subsubsection{Influence of ammonium concentration}

The ability of heterotrophic organisms to oxidise ammonia as a sole nitrogen source has been generally linked to aerobic denitrification. P.denitrificans ISTOD1 demonstrated an ability to remove ammonium at a concentration range of 100 to $350 \mathrm{mg} / \mathrm{L}$ [Medhi et al., 2017]. In this study, $50 \mathrm{mg} / \mathrm{L} \mathrm{NH}_{4}^{+}-\mathrm{N}$ was also included to observe the ammonium removal efficiency at lower concentration range. Ammonium removal efficiency was observed at all the three $(48.7 \pm 0.5,104.80 \pm 1.67$, $351.68 \pm 4.69 \mathrm{mg} / \mathrm{L} \mathrm{NH}_{4}{ }^{+}-\mathrm{N}$ ) different concentrations. The strain exhibited the maximum removal efficiencies of $80 \%, 86 \%$ and $76 \%$ at the end of $48 \mathrm{~h}$ under the three concentrations respectively as depicted in 
Table 1: Experimental runs suggested by BBD model for optimization of 3 factors for minimum generation 2 responses

\begin{tabular}{|c|c|c|c|c|c|c|}
\hline & & Factor 1 & Factor 2 & Factor 3 & Response 1 & Response 2 \\
\hline Std & Run & A: C:N ratio & $\begin{array}{c}\text { B: Duration } \\
\mathrm{h}\end{array}$ & C: $\mathrm{pH}$ & $\begin{array}{c}\text { Conc. of ammonia } \\
\mathrm{mg} / \mathrm{L}\end{array}$ & $\begin{array}{c}\text { Conc. of nitrate } \\
\mathrm{mg} / \mathrm{L}\end{array}$ \\
\hline 3 & 1 & 10 & 168 & 7 & 40.82 & 1.02 \\
\hline 17 & 2 & 55 & 96 & 7 & 0.4 & 1.47 \\
\hline 10 & 3 & 55 & 168 & 4 & 29.71 & 16.7 \\
\hline 1 & 4 & 10 & 24 & 7 & 4.5 & 2.31 \\
\hline 6 & 5 & 100 & 96 & 4 & 28.61 & 12.11 \\
\hline 14 & 6 & 55 & 96 & 7 & 0.42 & 1.45 \\
\hline 16 & 7 & 55 & 96 & 7 & 0.42 & 1.46 \\
\hline 9 & 8 & 55 & 24 & 4 & 15.83 & 10.03 \\
\hline 15 & 9 & 55 & 96 & 7 & 0.46 & 1.42 \\
\hline 12 & 10 & 55 & 168 & 10 & 13.57 & 10.52 \\
\hline 11 & 11 & 55 & 24 & 10 & 15.94 & 10.03 \\
\hline 5 & 12 & 10 & 96 & 4 & 30.94 & 5.12 \\
\hline 2 & 13 & 100 & 24 & 7 & 15.37 & 16.83 \\
\hline 7 & 14 & 10 & 96 & 10 & 32.63 & 3.74 \\
\hline 13 & 15 & 55 & 96 & 7 & 0.4 & 1.45 \\
\hline 8 & 16 & 100 & 96 & 10 & 33.21 & 8.37 \\
\hline 4 & 17 & 100 & 168 & 7 & 0.62 & 3.84 \\
\hline
\end{tabular}

Fig.1a. Among the three concentrations, the heterotrophic nitrification was demonstrated best using $100 \mathrm{mg} / \mathrm{L}$ and therefore, this concentration was fixed as nitrogen source in further analysis as well as for optimization analysis. Previous studies have indicated that several strains were capable of removing a single concentration of ammonia. Ammonia removal efficiency of $75 \%$ and $80 \%$ by Paracoccus versutus LYM and Serratia marcescens W5 was observed using $100 \mathrm{mg} / \mathrm{L} \mathrm{NH}^{+}-\mathrm{N}$ [Shi et al., 2013; Wang et al., 2016]. As comparison to other studies the strain ISTOD1 appears to be a better strain of ammonium oxidation.

\subsubsection{Influence of carbon sources}

Carbon sources considerably affect the growth and rate of hetrotrophic nitrification and aerobic denitrification. Experiments were conducted to determine the effect of glucose, sucrose and molasses as sole carbon sources on growth and $\mathrm{NH}_{4}{ }^{+} \mathrm{N}$ removal efficiency by the strain ISTOD1 as shown in Fig. 1b. Glucose and sucrose accelerated the growth of the bacterial strain and thus $\mathrm{OD}_{600}$ reached the peaks at $24 \mathrm{~h}$, slowly rising till $48 \mathrm{~h}$ until it came to a stationary phase after $72 \mathrm{~h}$. In presence of molasses, there was a steady growth but at $24 \mathrm{~h}$ the $\mathrm{OD}_{600}$ reached 0.72 as compared to glucose and sucrose where the $\mathrm{OD}_{600}$ reached 1.88 and 1.63 respectively. In correlation with the growth, ammonia was also reduced simultaneously. Accordingly, the $\mathrm{NH}_{4}{ }^{+}-\mathrm{N}$ removal efficiency within 24 was $50.4 \%, 31.8 \%$ and $44.1 \%$ whereas within $48 \mathrm{~h} 83.9 \%, 47.5 \%$ and $78.4 \%$ was respectively in presence of glucose, sucrose and molasses. As the results indicated, the strain ISTOD1 tends to choose glucose followed by molasses and sucrose. Glucose was also used for reporting aerobic nitrification- denitrification by $P$. retgerri YL [Zhao et al., 2010]. In our study, the possible reason of preferring glucose by strain ISTOD1 might be explained that glucose being a monosaccharide (simple molecular structure) can be easily utilized by the bacteria and the reducibility of glucose stimulate the heterotrophic nitrification-aerobic denitrification process. Unlike from strain ISTOD1, heterotrophic nitrogen removal strains like $A$. faecalis $\mathrm{NR}$ showed a $\mathrm{NH}_{4}^{+}-$ $\mathrm{N}$ removal efficiency of $98.9 \%$ with citrate followed by $94.9 \%$ with glucose as the carbon source and Bacillus cereus GS-5 showed $94.4 \%$ $\mathrm{NH}_{4}{ }^{+}$- $\mathrm{N}$ removal efficiency with acetate and $64 \%$ with glucose as the carbon source [Zhao et al., 2017; Rout et al., 2017]. It was also reported that glucose requires enzymatic conversion before entering into metabolism, unlike citrate or acetate directly enters metabolism without any modifications [Guo et al., 2016]. These results imply that the use of organic carbon significantly affects the growth and substrate removal efficiency and the type of carbon source and bacteria both influences the bacterial performance.

\subsubsection{Effect of $\mathrm{pH}$ and temperature in ammonium removal}

The influence of the other two experimental parameters, $\mathrm{pH}$ and temperature are depicted in Fig. 1c. The growth as well as nutrient removal ability of the strain ISTOD1 at various $\mathrm{pH}(4,7,10)$ and temperature $\left(15^{\circ} \mathrm{C}, 30^{\circ} \mathrm{C}, 45^{\circ} \mathrm{C}\right)$ were investigated. Growth was observed in the entire $\mathrm{pH}$ range with maximum growth obtained at $\mathrm{pH} 7$ followed by $\mathrm{pH} 10$ and then $\mathrm{pH} 4$. At $\mathrm{pH} 7$, the cell growth value with $\mathrm{OD}_{600}$ was found to be 0.8 at $24 \mathrm{~h}$ steadily increases till $\mathrm{OD}_{600}$ of 1.16 after $48 \mathrm{~h}$ of incubation, whereas in $\mathrm{pH} 10$ the growth was slow and at $48 \mathrm{~h} \mathrm{OD}$ reached 0.26 from 0.06 . In the case of $\mathrm{pH} 4$, the growth was minimal showing $\mathrm{OD}_{600}$ of 0.15 which indicates that acidic conditions inhibited the bacterial proliferation. The nutrient removal efficiency of the strain followed exactly the same trend exhibiting $75.7 \%, 37 \%$ and $17.8 \%$ at $\mathrm{pH}$ 7,10 and 4 respectively. Previous studies have reported maximum nutrient removal in neutral or slightly alkaline condition since it usually facilitates the heterotrophic nitrification process by making more free ammonia available in the medium and moreover, acidic or alkaline conditions are harmful to the microbes [Huang et al., 2017; Rout et al., 2017]. Maximum heterotrophic nitrogen removal was also shown by $P$. retgerri $\mathrm{YL}$ as well as P.stutzeri $\mathrm{T} 1$ after $96 \mathrm{~h}$ incubation at $\mathrm{pH} 7$ [Zhao et al., 2010; Guo et al., 2013]. Taking into account the results, $\mathrm{pH} 7$ was fixed as the optimum parameter strain ISTOD1 and was selected for further optimization experiments.

Fig. 1d shows the effect of temperature on the growth adaptability and $\mathrm{NH}_{4}{ }^{+} \mathrm{N}$ removal efficiency of strain ISTOD1. The selected bacterial strain was able to grow and remove ammonium successfully at a broad range of temperature. It was also observed in this study that the microbial growth was also affected by the temperature. Maximum cell density at 24 $\mathrm{h}$ reached an $\mathrm{OD}_{600}$ of 0.039 at $15^{\circ} \mathrm{C}, 0.464$ at $30^{\circ} \mathrm{C}$ and 0.048 at $45^{\circ} \mathrm{C}$ while at $48 \mathrm{~h}$ reached an $\mathrm{OD}_{600}$ of 0.06 at $15^{\circ} \mathrm{C}, 1.30$ at $30^{\circ} \mathrm{C}$ and 0.089 at $45^{\circ} \mathrm{C}$. Even after that, a steady growth was obtained from strain ISTOD1 till $120 \mathrm{~h}$ showing adaptability to $15^{\circ} \mathrm{C}$ and $45^{\circ} \mathrm{C}$ (data not shown). Along with cell growth the $\mathrm{NH}_{4}^{+}-\mathrm{N}$ removal efficiency also correlated well with temperature. The $\mathrm{NH}_{4}^{+}-\mathrm{N}$ removal percentage increased from $5.46 \%$ at $15^{\circ} \mathrm{C}$ to $76.23 \%$ at $30^{\circ} \mathrm{C}$ after $48 \mathrm{~h}$ of nutrient removal. Further increasing in temperature to $45^{\circ} \mathrm{C}$ resulted in a remarkable decrease in the ammonium removal efficiency showing removal percentage of only $9.31 \%$. Most of the studies were comparable to the results obtained in the present study and have reported strains having an optimum temperature of $30^{\circ} \mathrm{C}-37^{\circ} \mathrm{C}$, such as Bacillus N13 at $30^{\circ} \mathrm{C}$ [Huang et al., 2017], Pseudomonas fluorescens wsw- 1001 at $30^{\circ} \mathrm{C}$ [Zhang et al., 2015], Bacillus cereus GS-5 at $35^{\circ} \mathrm{C}$ [Rout et al., 2017] and strain ISTOD1 from this 

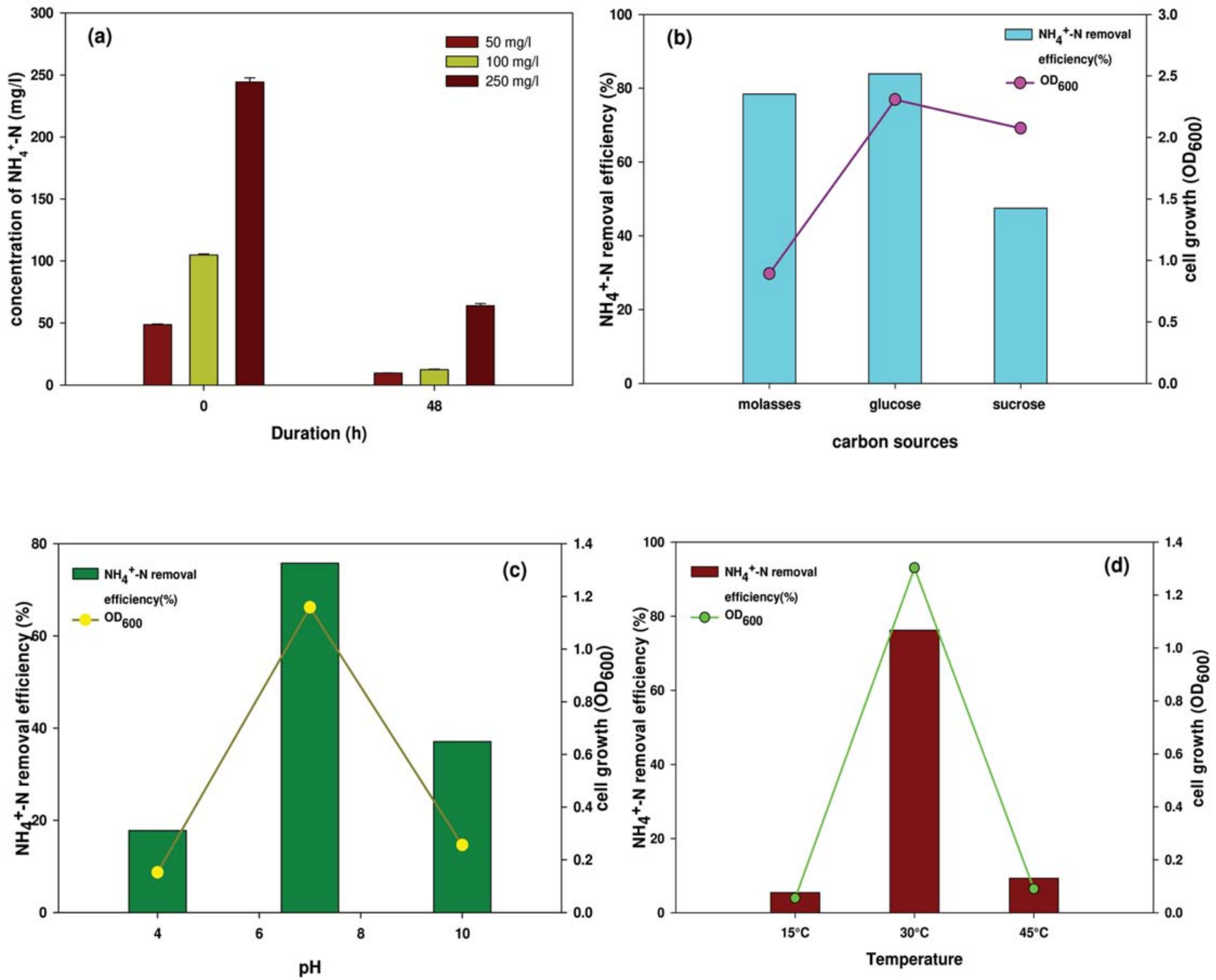

Fig. 1. Pre-optimized conditions for ammonia-N removal by P.denitrificans ISTOD1 under (a) initial ammonium concentration (b) presence of carbon sources (c) $\mathrm{pH}$ (d) temperature

study. Current studies have described that heterotrophic nitrification and aerobic denitrification are mainly carried out in mesophilic conditions [Wang et al., 2016] and moreover nitrification process is temperature sensitive likely due to the alterations in enzyme activity of ammonia monooxygenase which is responsible for heterotrophic nitrification [Huang et al., 2017]. In natural water environments, the temperature is rarely higher than $30^{\circ} \mathrm{C}$ and therefore it was set up as the optimum range for further research.

\subsection{Process optimization by RSM}

Response surface methodology (RSM) was used to enhance the treatment performance for nitrogen removal (ammonia and nitrate) by P.denitrificans ISTOD1. The factors $\mathrm{C}: \mathrm{N}$ ratio, $\mathrm{pH}$ and duration were optimized and the quadratic response matrix were created using BoxBehnken design (BBD), which is one of the designs in RSM (Table 1). The relationship between these three factors and two responses (concentration of ammonia (mg/L) and concentration of nitrate $(\mathrm{mg} / \mathrm{L})$ ) were derived with the help of quadratic equations. The regression equation coefficients were evaluated and the data fitted to a second-order polynomial equation for ammonia and nitrate removal of the SBM culture supernatant. The quadratic equations derived from BBD were used to describe the relationship between the two responses in terms of coded factors and nitrogen concentrations as suggested by software were as follows:

$$
\begin{aligned}
\text { Conc. Of Ammonia(mg/L) }= & +0.4200-3.89^{*} \mathrm{~A}+4.14^{*} \mathrm{~B}-1.22^{*} \\
& \mathrm{C}-12.77^{*} \mathrm{AB}+0.7275^{*} \mathrm{AC}-4.06^{*} \\
& \mathrm{BC}+13.75^{*} \mathrm{~A}^{2}+1.16^{*} \mathrm{~B}^{2}+17.18^{*} \mathrm{C}^{2}
\end{aligned}
$$

Conc. Of Nitrate $(\mathrm{mg} / \mathrm{L})=$ $+1.45+3.62^{*} \mathrm{~A}-0.8900^{*} \mathrm{~B}-1.41^{*}$
$\mathrm{C}-2.92^{*} \mathrm{AB}-0.5900^{*} \mathrm{AC}-1.55^{*}$
$\mathrm{BC}+0.0325^{*} \mathrm{~A}^{2}+4.52 * \mathrm{~B}^{2}+5.85^{*} \mathrm{C}^{2}$

Where, $\mathrm{A}=\mathrm{C}: \mathrm{N}$ ratio, $\mathrm{B}=$ Duration and $\mathrm{C}=\mathrm{pH}$

Analysis of variance (ANOVA) was used to define the adequacy of the model. The following values were obtained for the two responses viz., concentration of ammonia and nitrate, respectively: Model F-value (14.52 and 5.25), "R-Squared" (0.9492 and 0.8710) and CV \% (31.75 and 46.79). The values indicated that the quadratic model was reproducible and in agreement with the experimental values (Fig. 2). The p-values are less than 0.05 for both the responses which establishes the significance of the model.

\subsubsection{Statistical analysis of factors on responses}

The comparison of the three factors in the coded equations (1 and 2) 
(a)

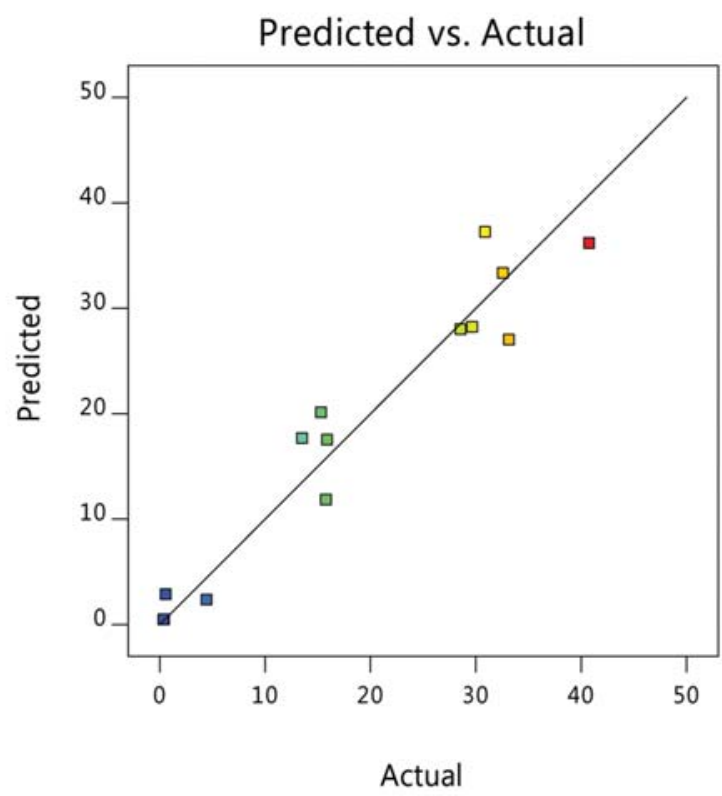

(b)

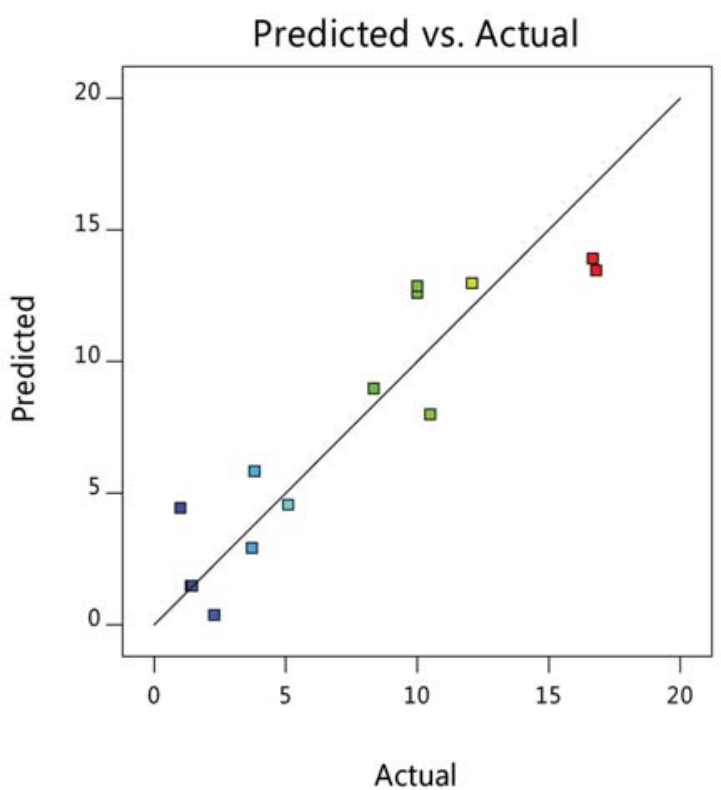

Fig.2. Graphical representation of the actual value obtained from experiments as compared to those predicted by the BBD model for responses: (a) concentration of ammonia and (b) concentration of nitrate

indicates that $\mathrm{C}: \mathrm{N}$ ratio and $\mathrm{pH}$ were negatively correlated while duration showed positive correlation to the concentration of ammonia. In case of concentration of nitrate, $\mathrm{C}: \mathrm{N}$ ratio was positively correlated while duration and $\mathrm{pH}$ were negatively correlated. A higher $\mathrm{C}: \mathrm{N}$ ratio promotes growth of heterotrophic nitrifying bacteria resulting into higher assimilation of ammonia and its conversion to nitrate which ultimately gets removed by denitrifcation process from the culture medium.

The effect of interactions of the three factors on the two responses was graphically represented through three-dimensional (3-D) plots as suggested by the model. In case of ammonia the graphs revealed a marked influence of low and high values of all the three factors where the positive correlation of $\mathrm{pH}$ and $\mathrm{C}: \mathrm{N}$ ratio with concentration of ammonia was represented by a hyperbolic sheet on the 3-D plot (Fig. 3c) exhibiting a depression towards the mid value of both the factors. The influence of duration with $\mathrm{C}: \mathrm{N}$ ratio and $\mathrm{pH}$ was represented by a parabolic curve (Fig. $3 \mathrm{a}$ and $3 \mathrm{e}$ ) where ammonium concentration varied linearly with duration in both cases, having much higher values towards extreme ends $(-1$ and +1$)$ when interacting with $\mathrm{C}: \mathrm{N}$ ratio as compared to its interaction with $\mathrm{pH}$. In case of response 2, the curves depict a parabolic influence of $\mathrm{pH}$ and duration whereas a linear influence of $\mathrm{C}: \mathrm{N}$ ratio. Therefore, the combined effect of $\mathrm{pH}$ and duration on the concentration of nitrate was represented by a similar hyperbolic sheet as in Fig. 3f while the interaction of $C: N$ ratio with $\mathrm{pH}$ and duration showed minimum values along the mid-range (Fig. $3 \mathrm{~b}$ and 3 -D). It was observed that neutral range of $\mathrm{pH}$, lower mid range of $C: N$ ratio and mid range of duration resulted in maximum removal of ammonia and nitrate concentrations.
According to previous studies that the nitrogen removal performance of some heterotrophic nitrifying and denitrifying bacteria are hampered in nitrification medium with a low and high $\mathrm{C}: \mathrm{N}$ ratio as they require optimum concentrations of organic compounds to assimilate ammonia [Joo et al., 2006; Huang et al., 2017; Taylor et al., 2009]. The linearly varying positive effect of duration on concentration of ammonia could possibly be due to the release of ammonium ions into the culture medium as a result of dead and decay of bacterial cells with exhaustion of available nutrients [Medhi et al., 2017]. The negatively varying effect of duration on concentration of nitrate could be due to an efficient aerobic denitrification process. Some studies have reported that the activity of the enzymes involved in nitrification-denitrification process declines at very low and high $\mathrm{pH}$ [Guo et al., 2016], which explains the negative effect of $\mathrm{pH}$ on both the responses.

\subsubsection{Validation results}

After analyzing the individual and interactive effects of the three factors, the optimized conditions predicted by the model (desirability value 0.977 ) were as follows: $\mathrm{pH}$ of $6.9, \mathrm{C}: \mathrm{N}$ ratio of 31.3 and duration of $53.3 \mathrm{~h}$ (Fig. 4). Validation experiments were set in triplicates with the above predicted optimal conditions resulted in $98.2 \%$ and $91.8 \%$ reduction in the concentration of $\mathrm{NH}_{4}{ }^{+}-\mathrm{N}$ and $\mathrm{NO}_{3}{ }^{-} \mathrm{N}$, respectively as compared to their values (12.43 and 8.84) under pre-optimized conditions as depicted in Table 2. The results thus establish the efficiency of bacteria in performing heterotrophic nitrification- aerobic denitrification process and applicability

Table 2: Concentration of ammonia $(\mathrm{mg} / \mathrm{L})$ and concentration of nitrate $(\mathrm{mg} / \mathrm{L})$ before and after optimization of process parameters

\begin{tabular}{|c|c|c|c|c|c|c|c|c|}
\hline \multirow{5}{*}{ Variable } & \multicolumn{2}{|c|}{ Optimization } & \multicolumn{3}{|c|}{ Conc. of ammonia(mg/L) } & & \multicolumn{2}{|c|}{ Conc. of nitrate (mg/L) } \\
\hline & \multicolumn{8}{|c|}{ condition } \\
\hline & \multirow[t]{3}{*}{ Before } & \multirow[t]{3}{*}{ After } & \multicolumn{3}{|c|}{ Optimization } & \multicolumn{3}{|c|}{ Optimization } \\
\hline & & & \multirow[t]{2}{*}{ Before } & \multicolumn{2}{|c|}{ After } & Before & \multicolumn{2}{|c|}{ After } \\
\hline & & & & Predicted & Experimental & & Predicted & Experimental \\
\hline $\mathrm{C}: \mathrm{N}$ ratio & 10 & 31.3 & & & & & & \\
\hline Duration (h) & 48 & 53.3 & 12.43 & 0.2378 & 0.2197 & 8.84 & 0.7595 & 0.7251 \\
\hline $\mathrm{pH}$ & 7.3 & 6.9 & & & & & & \\
\hline
\end{tabular}




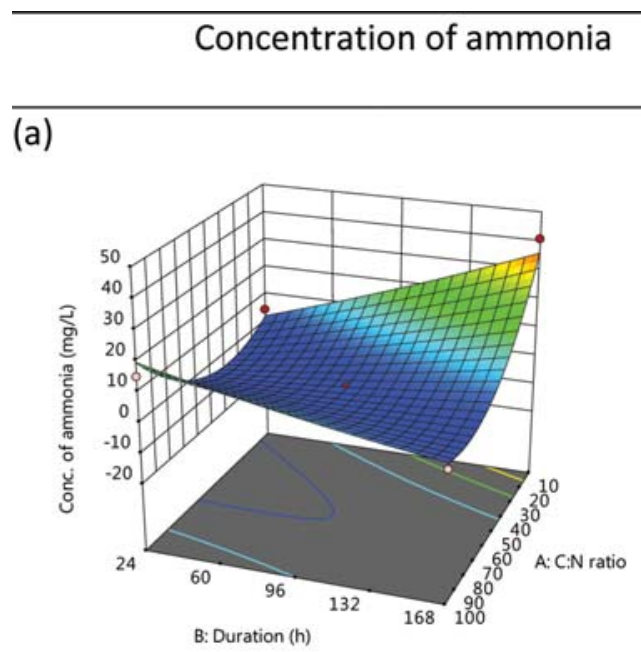

\section{Concentration of nitrate}

(b)

(c)

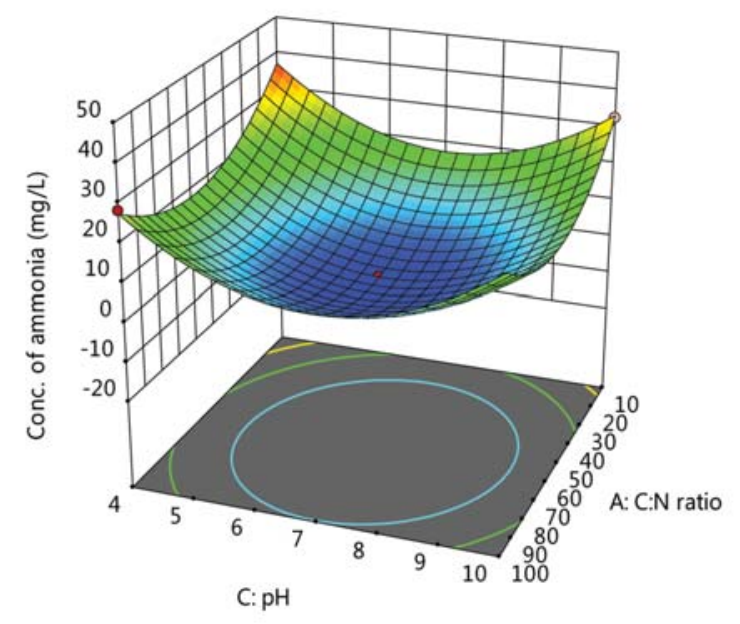

(e)

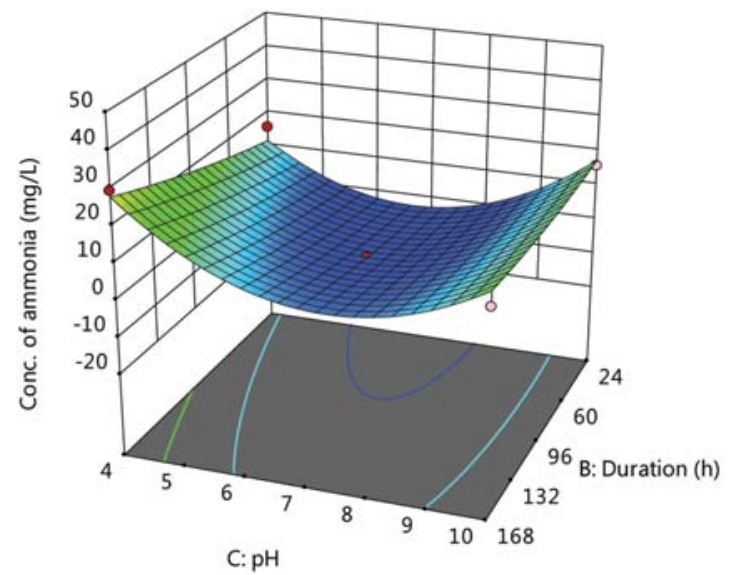

(d)
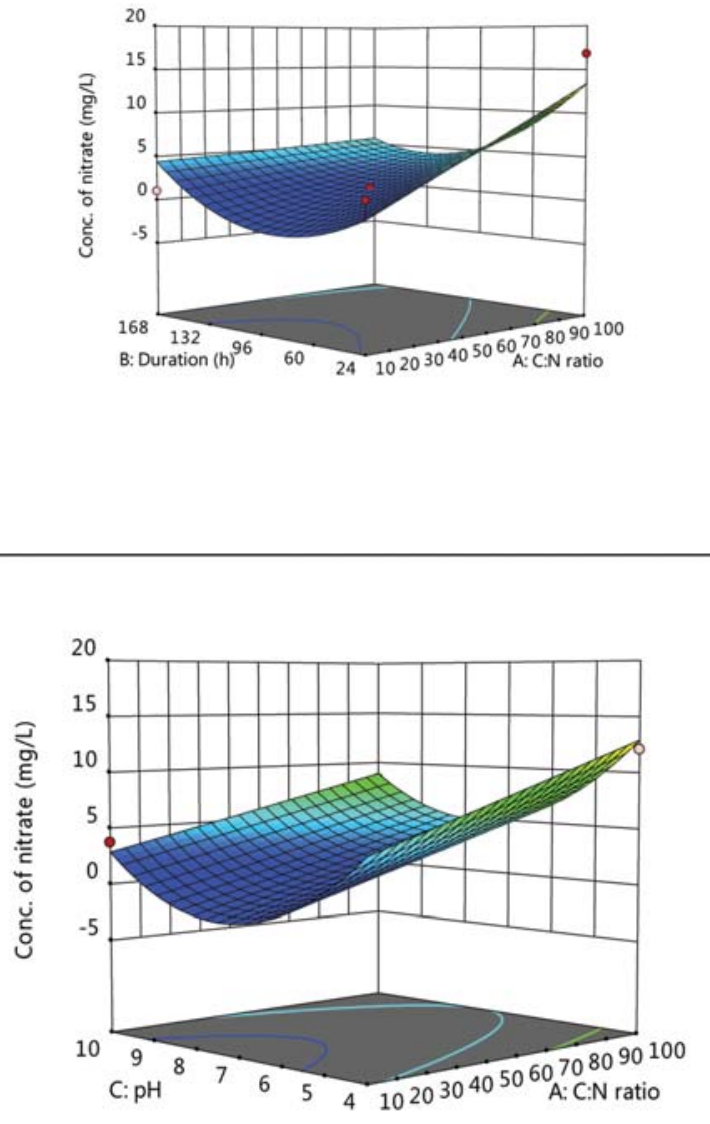

(f)

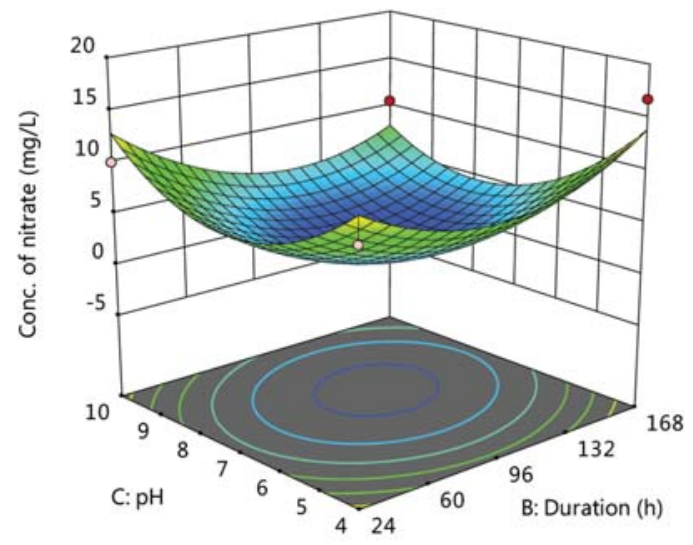

Fig.3. 3-D response surface graphs showing interaction among the three factors on: concentration of ammonia $(a, c, e)$ and concentration of nitrate $(b, d, f)$. 

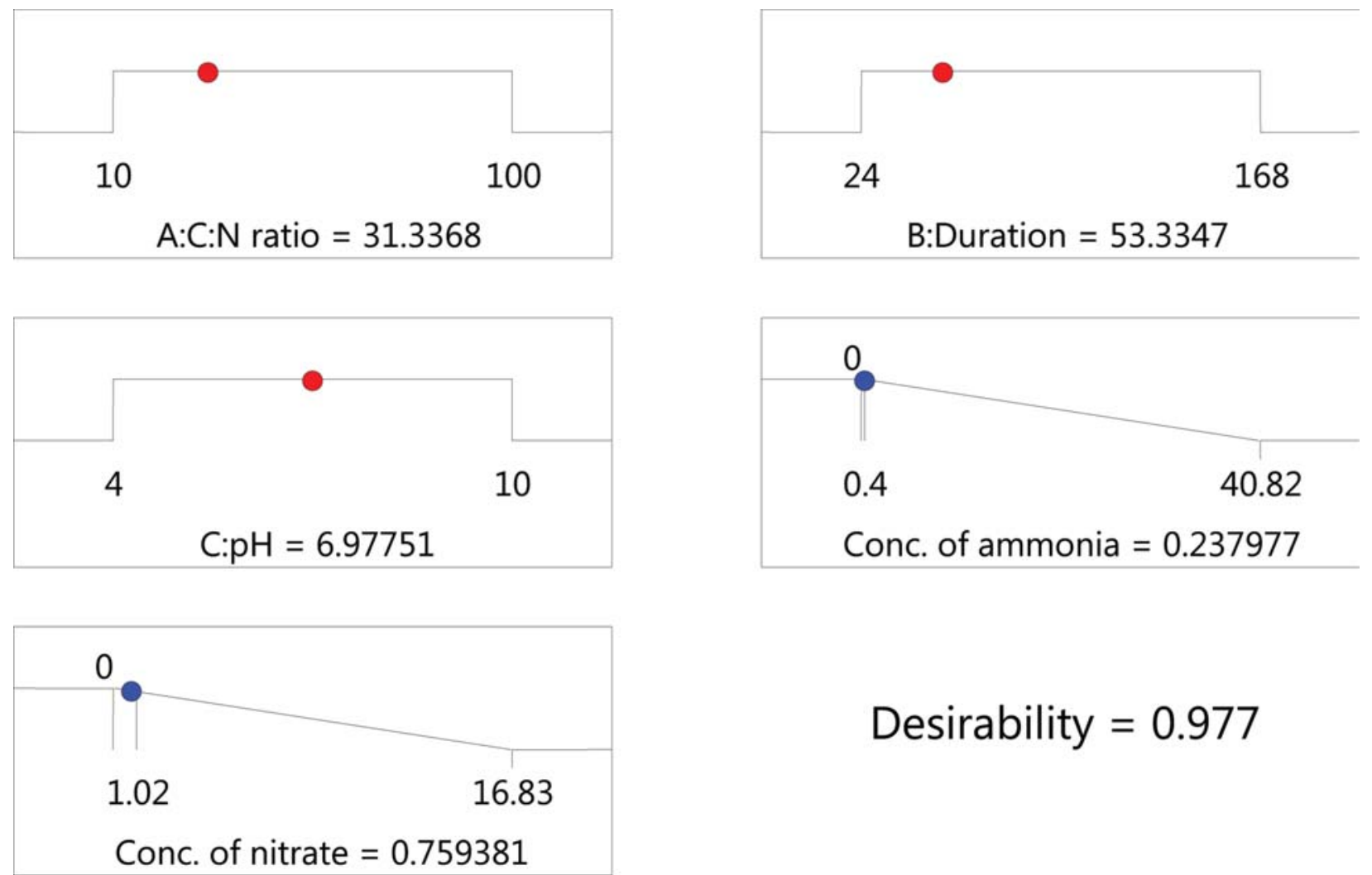

\section{Desirability $=0.977$}

Fig.4. Validation ramps obtained by the BBD model showing the predicted optimized values of factors for minimum response generation.

and efficiency of the model in the process optimization. Chen and $\mathrm{Ni}$ [2012] demonstrated the maximal ammonium removal was obtained after analyzing with RSM using the optimal conditions for $\mathrm{pH}$, temperature, C:N ratio and shaking speed. Zheng et al. [2017] also reported maximum ammonia removal rate of $0.59 \pm 0.04 \mathrm{mg} / \mathrm{L}$ when strain $\mathrm{HITLi}^{\mathrm{T}}$ was cultured in medium with optimized trace elements solution obtained from RSM analysis.

\subsection{Nitrogen balance during heterotrophic nitrification-aerobic denitrification process}

To study the nitrogen transformation, the balance of total nitrogen in the heterotrophic nitrification-aerobic denitrification process carried out by the strain ISTOD1 was measured and evaluated after the validation experiment was conducted using the optimized parameters obtained by RSM from both the media and the cells. All data were average values in the experimental period. The removal of $\mathrm{NH}_{4}^{+}-\mathrm{N}$ using glucose as carbon source for bacterial growth took place simultaneously, indicating it was a true heterotrophic process. Table 3 depicts the nitrogen balance profile of the degradation of $\mathrm{NH}_{4}^{+}-\mathrm{N}$ taken as the sole $\mathrm{N}$-source and the total nitrogen (TN). The initial $\mathrm{NH}_{4}^{+}-\mathrm{N}$ concentration was $99.31 \mathrm{mg} / \mathrm{L}$. With the decrease of ammonia nitrogen, the accumulations of nitrate occurred but the concentrations were very low, while nitrite was undetectable showing its prominent nitrogen removal ability. At the end of cultivating for $53 \mathrm{~h}$, $\mathrm{NH}_{4}{ }^{+} \mathrm{N}$ was calculated to $0.28 \mathrm{mg} / \mathrm{L}$ showing $99.72 \%$ of ammonia being removed accompanied with the trace amount accumulations of nitrate and a portion of $\mathrm{NH}_{4}{ }^{+} \mathrm{N}$ converted to form intracellular $\mathrm{N}$. After comparing the initial and final TN concentration, $67 \%$ of the initial nitrogen was removed from SBM probably dissimilated by strain ISTOD1 to form gas products or gaseous nitrogen. While, on the other hand, $32.4 \%$ of nitrogen was assimilated into the biomass in the heterotrophic nitrification-aerobic denitrification process by P.denitrificans ISTOD1. Considering the measurement errors caused by different analytic methods, the nitrogen was balanced. Similar studies reported that $S$. marcescens W5 was able to convert $51.06 \%$ of $\mathrm{NH}_{4}{ }^{+}$- $\mathrm{N}$ [Wang et al., 2016], $84.4 \%$ for

Table 3: Nitrogen balance by strain ISTOD1 after utilizing $\mathrm{NH}_{4}^{+}-\mathrm{N}$ as the sole nitrogen source.

Initial

Final amount of $\mathrm{N}(\mathrm{mg} / \mathrm{L})$

$\mathrm{NO}_{2}{ }^{-} \mathrm{N}$

$\mathrm{NO}_{3}{ }^{-} \mathrm{N}$

Intracellular

$\mathrm{NH}_{4}^{+}-\mathrm{N}$

$\mathrm{NH}_{4}{ }^{+}-\mathrm{N}$

(mg/L)
$\mathrm{N}$ lost(mg/L)

\begin{tabular}{|c|c|c|c|c|c|}
\hline $99.3086 \pm$ & $0.2197 \pm 0.30$ & 0.0 & $0.7251 \pm 0.02$ & $32.1445 \pm$ & $66.3201 \pm 0.2$ \\
\hline 0.114 & & & & 1.88 & \\
\hline
\end{tabular}


Vibrio sp. Y1-5 [Li et al., 2017], while Acinetobacter calcoaceticus HNR is able to convert $40.23 \%$ of $\mathrm{NH}^{+}-\mathrm{N}$ to $\mathrm{N}_{2}$ [Zhao et al., 2010], about $60 \%$ for Pseudomonas stutzeri strain T1 [Guo et al., 2013]. Compared to them, strain ISTOD1 also had efficient nitrogen removal abilities.

\section{Conclusion}

The present study focuses on the bioremoval ability of nitrogen by P.denitrificans ISTOD1, isolated from wastewater samples. Almost all $\mathrm{NH}_{4}{ }^{+}-\mathrm{N}$ and $\mathrm{NO}_{3}{ }^{-} \mathrm{N}$ was removed under aerobic condition. The preference of glucose followed by molasses and sucrose exhibited the strain to be a heterotrophic bacterium. The work highlighted the potency of bacterial strain in effectively utilizing ammonia from wastewaters containing a high $\mathrm{C}: \mathrm{N}$ ratio and also demonstrated the efficiency of $\mathrm{BBD}$ model in optimization of process parameters. The nitrogen balance, as a consequence revealed that a part of nitrogen was assimilated into the bacterial biomass whereas another part dissimilated into gaseous products. All results implied that the strain ISTOD1 had a promising prospect in the present day scenario in utilization and removal of nitrogen for enhancing wastewater treatment practices.

\section{Acknowledgements}

We are grateful to RGNF (UGC) and UGC, New Delhi, Government of India for providing fellowship and research grants. We are thankful to Dharmendra Kumar Dubey in the editing of the manuscript.

\section{Conflict of intertest}

The authors declare that they have no competing interests

\section{References}

1. American Public Health Association, 2012. Standard methods for the examination of water and wastewater, 22nd ed., American Public Health Association, Washington, DC

2. Asadi N, Zilouei H, 2017, Optimization of organosolv pretreatment ofrice straw for enhanced biohydrogen production using Enterobacteraerogenes. Bioresource technology, 227, 335-344.

3. Baker SC, Ferguson SJ, Ludwig B, Page MD, Richter OM, van Spanning RJ, 1998, Molecular genetics of the genus Paracoccus, metabolically versatile bacteria with bioenergetic flexibility, Microbiology and Molecular Biology Reviews, 62 , 10461078.

4. Central Pollution Control Board, 2010. Guide Manual: Water and Wastewater Analysis, Pollution Control Agency, New Delhi.

5. Chen Q, Ni J, 2012, Ammonium removal by Agrobacterium sp. LAD9 capable of heterotrophic nitrification-aerobic denitrification, Journal of bioscience and bioengineering, 113(5), 619-23.

6. Duan J, Fang H, Su B, Chen J, Lin J, 2015, Characterization of a halophilic heterotrophic nitrification-aerobic denitrification bacterium and its application on treatment of saline wastewater, Bioresource technology,179, 421-8.

7. Gao M, Qiu J, Li C, Wang L, Li H, Gao C, 2014, Modeling nitrogen loading from a watershed consisting of cropland and livestock farms in China using ManureDNDC. Agriculture, Ecosystems \& Environment, 185, 88-98.

8. Ge Q, Yue X, Wang G, 2015, Simultaneous heterotrophic nitrification and aerobic denitrification at high initial phenol concentration by isolated bacterium Diaphorobacter sp. PD7, Chinese Journal of Chemical Engineering, 23 (5), 835841.

9. Grguric G, Wetmore SS, Fournier RW, 2000, Biological denitrification in a closed seawater system, Chemosphere, 40(5), 549-55.

10. Guo L, Chen Q, Fang F, Hu Z, Wu J, Miao A, Xiao L, Chen X, Yang L, 2013, Application potential of a newly isolated indigenous aerobic denitrifier for nitrate and ammonium removal of eutrophic lake water, Bioresource technology,142, 4551.
11. Guo LJ, Zhao B, An Q, Tian M., 2016, Characteristics of a novel aerobic denitrifying bacterium, Enterobacter cloacae strain HNR, Applied biochemistry and biotechnology, 178(5), 947-59.

12. Gupta A, Thakur IS, 2015, Biodegradation of wastewater organic contaminants using Serratia sp. ISTVKR1 isolated from sewage sludge, Biochemical Engineering Journal, 102, 115-124

13. Gupta A, Thakur IS, 2016, Study of optimization of wastewater contaminant remova along with extracellular polymeric substances (EPS) production by a thermotolerant Bacillus sp. ISTVK1 isolated from heat shocked sewage sludge, Bioresource Technology, 213, 21-30.

14. Huang F, Pan L, Lv N, Tang X, 2017, Characterization of novel Bacillus strain N31 from mariculture water capable of halophilic heterotrophic nitrification-aerobic denitrification, Journal of bioscience and bioengineering, 124(5), 564-571.

15. Joo HS, Hirai M, Shoda M, 2006, Piggery wastewater treatment using Alcaligenes faecalis strain No. 4 with heterotrophic nitrification and aerobic denitrification, Water Research, 40 (16), 3029-3036.

16. Li Y, Wang Y, Fu L, Gao Y, Zhao H, Zhou W, 2017, Aerobic-heterotrophic nitrogen removal through nitrate reduction and ammonium assimilation by marine bacterium Vibrio sp. Y1-5, Bioresource technology, 230, 103-11.

17. Medhi K, Singhal A, Chauhan DK, Thakur IS, 2017, Investigating the nitrification and denitrification kinetics under aerobic and anaerobic conditions by Paracoccus denitrificans ISTOD1, Bioresource technology, 242, 334-43.

18. Robertson LA, Kuenen JG, 1984, Aerobic denitrification: a controversy revived, Archives of Microbiology, 139(4), 351-4.

19. Rout PR, Bhunia P, Dash RR, 2017, Simultaneous removal of nitrogen and phosphorous from domestic wastewater using Bacillus cereus GS-5 strain exhibiting heterotrophic nitrification, aerobic denitrification and denitrifying phosphorous removal, Bioresource technology, 244,484-95.

20. Shi Z, Zhang Y, Zhou J, Chen M, Wang X, 2013, Biological removal of nitrate and ammonium under aerobic atmosphere by Paracoccus versutus LYM, Bioresource technology, 148,144-8.

21. Song ZF, An J, Fu GH, Yang XL, 2011, Isolation and characterization of an aerobic denitrifying Bacillus sp. YX-6 from shrimp culture ponds. Aquaculture, 319(1-2) 188-93.

22. Taylor SM, He Y, Zhao B, Huang J, 2009, Heterotrophic ammonium removalcharacteristics of an aerobic heterotrophic nitrifying-denitrifying bacterium, Providencia rettgeri YL, Journal of Environmental Sciences, 21 (10), 1336-1341.

23. van Niel EW, Braber KJ, Robertson LA, Kuenen JG, 1992, Heterotrophic nitrification and aerobic denitrification inAlcaligenesfaecalis strain TUD, Antonie van Leeuwenhoek, 62(3), 231-7.

24. Wang T, Dang Q, Liu C, Yan J, Fan B, Cha D, Yin Y, Zhang Y, 2016, Heterotrophic nitrogen removal by a newly-isolated alkalitolerant microorganism, Serratia marcescens W5, Bioresource Technology, 211, 618-627.

25. Yang XP, Wang SM, Zhang DW, Zhou LX, 2011, Isolation and nitrogen remova characteristics of an aerobic heterotrophic nitrifying-denitrifying bacterium, Bacillus subtilis A1, Bioresource Technology,102(2), 854-62.

26. Yao S, Ni J, Ma T, Li C, 2013, Heterotrophic nitrification and aerobic denitrification at low temperature by a newly isolated bacterium, Acinetobacter sp. HA2. Bioresource technology, 139, 80-6.

27. Zhang S, Sha C, Jiang W, Li W, Zhang D, Li J, Meng L, Piao Y, 2015, Ammonium removal at low temperature by a newly isolated heterotrophic nitrifying and aerobic denitrifying bacterium Pseudomonas fluorescens wsw-1001, Environmental technology, 36(19), 2488-94.

28. Zhao B, He YL, Huang J, Taylor S, Hughes J, 2010, Heterotrophic nitrogen remova by Providencia rettgeri strain YL, Journal of Industrial Microbiology \& Biotechnology, 37(6), 609-16.

29. Zhao B, Tian M, An Q, Ye J, Guo JS, 2017, Characteristics of a heterotrophic nitrogen removal bacterium and its potential application on treatment of ammonium-rich wastewater, Bioresource technology, 226, 46-54.

30. Zheng Z, Li W, Huang X, Qin W, 2017, Effect of trace elements and optimization of their composition for the nitrification of a heterotrophic nitrifying bacterium, Acinetobacter harbinensis HITLi7 T, at low temperature, Annals of Microbiology, 67(11), 715-25. 